\title{
AN ALDERFER PERSPECTIVE OF THE HIGHER EDUCATION RESTRUCTURING IN SOUTH AFRICA
}

\author{
CA ARNOLDS \\ cecil.arnolds@nmmu.ac.za \\ Department of Business Management \\ Nelson Mandela Metropolitan University \\ Port Elizabeth
}

\begin{abstract}
The consequences of the restructuring of higher education in South Africa have not yet been thoroughly investigated. This study investigates the impact of the abovementioned restructuring on employee motivation (as measured by Alderfer's ERG theory), organisational commitment and job performance.

The results show that the respondents exhibit low levels of organisational commitment and low satisfaction with monetary remuneration and fringe benefits. The results, however, show high levels of satisfaction with growth factors, peer relations and performance intentions. These results are interpreted in the light of the multiple regression analyses conducted of the interrelationships among the variables.
\end{abstract}

\section{OPSOMMING}

Die nagevolge van die herkonstruksie van hër-onderwys in Suid-Afrika is nog nie deeglik ondersoek nie. Hierdie studie ondersoek die invloed wat bogenoemde rekonstruksie op die motivering (soos gemeet deur Alderfer se teorie), organisatories toegewydheid en werksprestasie van werknemers het.

Die resultate toon dat die respondente lae vlakke van organisatoriese toegewydheid en lae tevredenheid ten opsigte van monetêre beloning en byvoordele tentoonstel. Die resultate toon egter hoë vlakke van tevredenheid in soverre groeifaktore, kollegiale verhoudinge en werkprestasievoornemens betref. Hierdie resultate word vertolk teen die agtergrond van veelvoudige regressie-analises wat op die inderlinge verwantskappe tussen die veranderlikes uitgevoer is.

As part of a global phenomenon, the South African highereducation system is presently undergoing a complex restructuring process of merging tertiary-education institutions. The consequences of this process for tertiary-education institutions have however not yet been thoroughly investigated. In business firms, for example, restructuring is reported to cause uncertainty, anxiety, loss of motivation, lower morale and higher levels of accidents and work errors (Clarke \& Koonce 1995; Hellriegel, Slocum \& Woodman 2001).

\section{Higher-education restructuring - a global phenomenon} The restructuring of higher-education institutions is not a uniquely South African phenomenon. Universities and colleges of education have undergone restructuring in many other countries, such as Canada, Australia, Russia, China, the United States of America and Britain (Blackmore, 2002; Curri, 2002; Finkelstein, 2003; Gumport, 2000; Mok, 2003; Wood \& Meek, 2002). Many reasons have been advanced for why it has been necessary for higher-education institutions to restructure, namely governments' diminishing ability to subsidise education, due to the restructuring of global capitalism and the emergence of neo-liberal macro-economics (Kraak, 2004; Manicas, 1998; Mok, 2003; Woodard, 1997); technological advances that have increased the demand for distance teaching (Mok, 2003); and socio-political changes in countries that have triggered the restructuring of their government institutions, including higher education (Finkelstein, 2003; Mok, 2003).

Restructuring of higher education has generally followed two approaches. Firstly, some governments have chosen the path of changing their modes of delivery and adopting new management strategies, such as privatisation (Mok, 2003). This restructuring "strategy" has been the result of the modern state's philosophy of decentralisation and autonomisation of higher education (Mok, 2003). In this approach, governments have relinquished almost the entire educational duty to private agencies. The second approach to the restructuring of higher education is consolidation, whereby previously separate institutions are integrated. This is the restructuring model

Requests for copies should be addressed to: cecil.arnolds.nmmu.ac.za followed by Canada, South Africa and Australia (Curri, 2002; Fourie, 1999).

Two types of consolidations have been identified, namely the federal model and the amalgamation or merger model. In the federal model, the consolidating institutions have kept their respective autonomy, while being managed by a central head office. In the merger model, the merging institutions have dissolved as separate institutions and united to become a new entity. This is the model for which the South African government has opted.

Research shortcomings

Despite the problems identified in the restructuring of higher education world-wide, a lack of quantitative research appears to exist on the human dimension involved in the process Marginson and Ramsden (2002) are for instance of the view that "practice has moved ahead of both theory and empirical investigation".

Curri (2002 and Fourie (1999) further highlighted the small samples on which previous studies were based as a major shortcoming in the research on higher-education restructuring. Only 24 people for example participated in the Curri (2002) study, while Fourie (1999) cited "the small pilot study" used in the Van Rensburg (1998) study.

In addition to the above shortcomings, it appears that most of the research reported on higher-education restructuring is of a qualitative nature. The Fourie (1999) "paper" is a qualitative analysis of previous research findings, which includes the Van Rensburg (1998) study.

The present study concurs with Viljoen and Rothman (2002 p. 9) that it is a serious shortcoming that no quantitative study has been done on the relationship between variables interacting within the human dimension of the restructuring situation. Problems such as inadequate leadership training and employee demotivation have been highlighted without any attempt to quantify the impact these variables would have on the organisational commitment and job performance of employees. 
The present study is an attempt to address the above-mentioned shortcomings by conducting a quantitative analysis of the relationship between employee motivation, organisational commitment and job performance in a restructuring highereducational institution.

\section{The research propositions}

Research has abundantly shown that restructuring in business firms causes uncertainty and anxiety among employees (Clark \& Koonce, 1995; Robbins, 1998). This uncertainty and anxiety often result in overt and covert resistance to the changes brought about by restructuring (Hellriegel, Slocum \& Woodman, 2001). Overt resistance to change manifests in strikes, reduced productivity, inferior work and even sabotage, while covert resistance is often expressed by increased tardiness and absenteeism, requests for transfers, resignations, loss of motivation, lower morale and higher levels of accidents and work errors.

In the South African and Australian experiences of highereducation restructuring, similar negative experiences with the process have been reported. Viljoen and Rothman (2002), for example, reported that the staff members of a South African merging tertiary institution they were investigating were very dissatisfied with how the restructuring process was managed by their management. Fourie (1999) is of the opinion that "the implications of institutional transformation for academic staff are much more profound and multifarious that is generally believed". She (Fourie, 1999) found that the academic staff in restructuring highereducation institutions in South Africa experience the same psychological states that terminally ill patients go through, namely denial, anger, bargaining, depression, and finally, acceptance. It is further believed that the merging of tertiaryeducational institutions in South Africa is the largest restructuring of higher-education in the world (Mkize, 2005), which suggests that the combined effect of these negative experiences could have serious implications for the entire South African higher-education system and eventually the national economy.

The Australian consolidation process was characterised by anxieties among staff about lowering of academic standards, cultural differences, overlapping of areas of specialisation, shift of power from academia to management and increased workloads (Mildred, 2002). There were also some concerns about reduced career advancement opportunities and the role that senior staff play in the appointments. Promotions were viewed as taking place on the basis of "whom you know" in the pre-merger institution (Mildred, 2002).

Against the background of the preceding literature review it can be expected that, due to negative perceptions, attitudes and feelings about organisational restructuring, employees in tertiary-education institutions will exhibit low levels of motivation, organisational commitment and job performance. It is therefore proposed that:

P1: As a result of organisational restructuring, employees in tertiary-education institutions will exhibit low levels of motivation

P2: As a result of organisational restructuring, employees in tertiary-education institutions will exhibit low levels of organisational commitment

P3: As a result of organisational restructuring, employees in tertiary-education institutions will exhibit low levels of job performance

\section{The hypotheses}

The present paper asserts that managers of higher-education institutions need to be concerned about how the abovementioned anxieties, anger, depression and possible enforced acceptance will influence the organisational commitment and job performance of their staff members. Several empirical studies have shown that organisational commitment is positively related to employee job performance (Boshoff \& Arnolds, 1995a; Mowday, Steers \& Porter, 1979; Zaccaro \& Dobbins, 1989). This implies that an increase in organisational commitment leads to an increase in employee job performance and vice versa.

Empirical results about the influence of elements of motivation, on the one hand, and organisational commitment and job performance, on the other hand, have been widely published (Alpander, 1990; Boshoff \& Arnolds, 1995b; Collarelli \& Bishop, 1990; Mottaz, 1989; Wallace, 1995). In the present study the Alderfer (1969) ERG theory of motivation is used to investigate the motivational elements that could impact upon the organisational commitment of employees in a restructuring tertiary-education institution. Compared to Maslow's (1943) needs hierarchy, the ERG theory has elicited more support from contemporary researchers as far as motivation in the work situation is concerned (Luthans, 1998; Robbins, 1998). According to Alderfer (1969), man is motivated by three groups of core needs, namely Existence, Relatedness and Growth needs, hence the term ERG theory. The existence needs manifest in the work place as the need for monetary remuneration and fringe benefits, while the relatedness needs are manifested in peer/co-worker relations. Growth needs represent the employee's desire for personal development and advancement (training, challenging assignments and promotion).

The relationship between the satisfaction of the Alderfer (1969) needs (pay, fringe benefits, peer relatedness and growth), on the one hand, and organisational commitment and job performance, on the other hand, has been the topic of numerous research articles. Some of these articles, for example, have shown that satisfaction with monetary remuneration (pay) is an important determinant of organisational commitment (Cohen, 1992; Colarelli \& Bishop, 1990; Oliver, 1990; Workplace changes employees want to see, 1999). Many studies have also reported a significant positive relationship between satisfaction with monetary remuneration and job performance (Arnolds \& Boshoff, 2000; Fox, Scott \& Donohue 1993; Hong, Yang, Wang, Chiou, Sun \& Huang, 1995).

Empirical studies have shown that employees' satisfaction with fringe benefits has a significantly positive influence their organisational commitment (Bennett, 2002b; Darden, Hampton \& Howell, 1989; Workplace changes employees want to see, 1999). McGregor (1987) and Prokopenko (1987) reported that satisfaction with fringe benefits is a positive determinant of an employee's job performance.

Research has also shown that commitment to co-workers (peer relatedness) is significantly and positively related to organisational commitment (Bagraim, 2003; Gregersen, 1993; Wallace, 1995) and job performance (Levine, 1994; Stein \& Hollowitz, 1992; Smith \& Tisak, 1993).

Satisfaction of growth needs (challenging assignments, utilisation of a wide range of abilities, learning new things and involvement in decision-making, and advancement opportunities) has been found to correlate positively and significantly with organisational commitment (Alpander, 1990; Bennett, 2002b; Boshoff \& Arnolds, 1995b). Research has also shown that employees who are not empowered through training and development (continuous learning and challenging assignments) would eventually become less committed to their organisations. Such employees will only remain with their organisations if financial benefits are satisfactory, while rendering mediocre performances (Falkenberg, 2001; Willemse, 2002). They will eventually leave their organisations, as they no longer experience their working environment as motivational. 
Based on the preceding literature review the following hypotheses were formulated:

H1 Organisational commitment exerts a positive influence on job performance

H2: Employee motivation, as measured by the satisfaction with pay, exerts a positive influence on organisational commitment

H3: Employee motivation, as measured by the satisfaction with pay, exerts a positive influence on job performance

H4: Employee motivation, as measured by the satisfaction with fringe benefits, exerts a positive influence on organisational commitment

H5: Employee motivation, as measured by the satisfaction with fringe benefits, exerts a positive influence on job performance

H6: Employee motivation, as measured by the satisfaction with peer relations, exerts a positive influence on organisational commitment

H7: Employee motivation, as measured by the satisfaction with peer relations, exerts a positive influence on job performance

H8: Employee motivation, as measured by growth need satisfaction, exerts a positive influence on organisational commitment

H9: Employee motivation, as measured by growth need satisfaction, exerts a positive influence on job performance

The hypothesised relationships described above are graphically depicted in Figure 1.

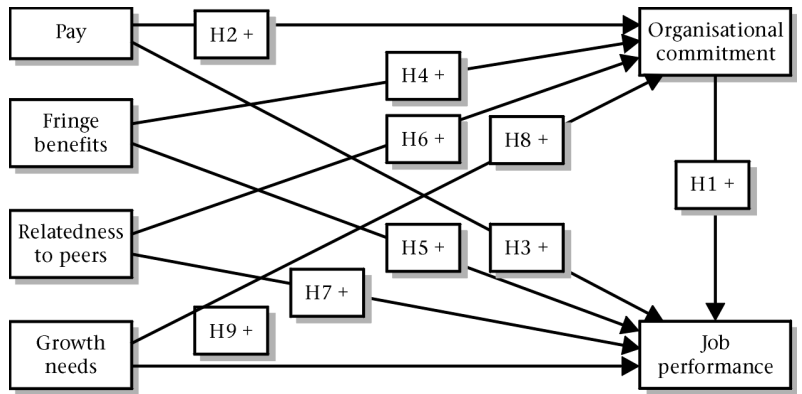

Figure: The hypothesised relationships

\section{RESEARCH DESIGN}

\section{Objective of the study}

The main objective of the study is to investigate what influence the present restructuring process exerts on the motivation, organisational commitment and job performance of the staff of a higher-education institution. More specifically, the study investigates the relationship between employee motivation (as measured by Alderfer's ERG theory of motivation), on the one hand, and organisational commitment and job performance (as measured by performance intent), on the other hand.

\section{Participants/respondents}

An electronic questionnaire was e-mailed to 1124 academic and non-academic staff members of a South African university. Onehundred-and-seventy (170) usable questionnaires were returned, which represents a response rate of $15.1 \%$.

The sample consisted of $37,1 \%$ males and $45,1 \%$ females, while $8.8 \%$ respondents did not indicate their gender. The age composition includes $12,4 \% 20$ to 29 -years olds and an even spread of respondents over the 30 to $39(24,7 \%), 40$ to 49 $(25,9 \%)$ and 50 to $59(22,9 \%)$ age groups. More than $50 \%$ of the respondents were academic staff, which include among others $2.9 \%$ heads of departments, $10,2 \%$ professors, $11,8 \%$ senior lecturers and $15,3 \%$ lecturers. The administrative staff include $2,4 \%$ directors and deputy directors, 3,5\% managers, $12,4 \%$ administrative officers (inventory, marketing, communication, financial and network administrators), 5,8\% librarians and 4,7\% secretaries and typists. About 38\% of the respondents were Afrikaans-speaking, about $41 \%$ English-speaking and 2,9\% Xhosa-speaking. As far as educational qualifications are concerned, $13,5 \%$ had a grade 12 plus a diploma, $8.8 \%$ grade 12 plus first degree, $11,9 \%$ an honours or equivalent degree, $12,9 \%$ a master's degree or MBA and $25.9 \%$ had a doctor's degree. Most of the respondents a job tenure ranging from less than 5 years to 19 years, while about $14 \%$ had a job tenure ranging from 20 to 30-plus years.

The sample composition reflects a fair representation of all the job categories in the institution, as they range from directors, professors, heads of departments to librarians, secretaries and typists, and many categories in between. Due to a lack of access to e-mail facilities, general workers (garden and cleaning and maintenance personnel) did not complete questionnaires and were therefore not included in the study. Another notable absence from the sample was chartered accountants. No reasonable explanation for this is offered other than to indulge in speculation.

Less than three percent of the sample were Xhosa-speaking. This can be attributed to the absence of general workers who are predominantly Xhosa-speaking at this university. It is also possible that some of the Xhosa-speaking respondents indicated their home language as English.

Against the above-mentioned background, it appears that the sample is representative of the population of the university as far as the job levels ranging from directorship to the lowest administrative level are concerned.

The measuring instruments

The shortened version of Alderfer's (1969) instrument was used to measure employee motivation, in other words, satisfaction with monetary remuneration, fringe benefits, peer relations and growth needs. Favourable results on the convergent and discriminant validation and reliability coefficients ranging from 0,64 to 0,90 were reported for these scales (Alderfer, 1969; Arnolds \& Boshoff, 2000).

Organisational commitment was measured using the shortened 9-item version of the Mowday, Porter and Steers (1982) Organisational Commitment Questionnaire (OCQ). The reliability and validity of both the short and long (15-item) versions have been adequately proven (Brooke, Russell \& Price, 1988; Matthieu \& Farr, 1991).

Performance intentions have been described as a potent predictor or measure of employee job performance (Carkhuff 1986; Hampton, Summer \& Webber 1982; Shore, Newton \& Thornton 1990; Sumerlin \& Norman, 1992). The performance intentions scale, developed by Shore et al. (1990), was used as a surrogate measure of job performance in this study. The reported reliability coefficients, which ranged from 0,60 to 0,84 , are regarded as sufficient to use this instrument to measure the performance intention construct (Shore et al., 1990).

The questions in all the above-mentioned instruments were anchored on a seven-point Likert scale.

For the purposes of this study a score of below $60 \%$ (a mean score of 4,2 on a 7-point scale) is regarded as an indication of low organisational commitment given that the global organisational commitment average ranges from 60 to 65 percent, while the South African average is 68\% (Bennett, 2002a). For the purposes of consistency the cut-off point of $60 \%$ is extended to the Alderfer needs and job performance as well. 


\section{RESULTS}

Internal reliability and discriminant validity of the measuring instruments

The internal reliability of the measuring instruments was assessed by calculating the Cronbach (1951) alpha coefficients of these instruments, using the computer program SAS (SAS Institute, 1988). Table 1 shows that all the instruments used in this study exhibit reliability coefficients that exceed the minimum reliability requirement $(0,70)$ according to Nunnally (1978).

TABLE 1

Cronbach Alpha values of measuring instruments

\begin{tabular}{lcc}
\hline $\begin{array}{l}\text { The measuring } \\
\text { instruments }\end{array}$ & $\begin{array}{c}\text { Initial } \\
\text { value }\end{array}$ & $\begin{array}{c}\text { Final } \\
\text { value }\end{array}$ \\
\hline Organisational commitment & 0,89 & 0,92 \\
Monetary remuneration (pay) & 0,86 & 0,86 \\
Fringe benefits & 0,93 & 0,93 \\
Peer relations & 0,85 & 0,85 \\
Growth needs & 0,82 & 0,82 \\
Job performance & 0,77 & 0,77 \\
\hline
\end{tabular}

Exploratory factor analysis was conducted to assess the discriminant validity of the measuring instruments. The computer program BMDP4M (Frane, Jennrich \& Sampson, 1990) was used for this purpose. Maximum likelihood was specified as the method of factor extraction and a Direct Quartimin oblique rotation of the original factor matrix was used (Jennrich \& Sampson, 1966).

TABLE 2

THE ROTATED FACTOR LOADINGS

\begin{tabular}{|c|c|c|c|c|c|c|}
\hline & $\begin{array}{c}\text { FACTOR } \\
1 \\
\text { Org. } \\
\text { commit- } \\
\text { ment }\end{array}$ & $\begin{array}{c}\text { FACTOR } \\
2 \\
\text { Fringe } \\
\text { benefits } \\
\text { peers }\end{array}$ & $\begin{array}{c}\text { FACTOR } \\
3 \\
\text { Related- } \\
\text { ness to }\end{array}$ & $\begin{array}{c}\text { FACTOR } \\
4 \\
\text { Pay }\end{array}$ & $\begin{array}{c}\text { FACTOR } \\
5 \\
\text { Growth } \\
\text { needs }\end{array}$ & $\begin{array}{c}\text { FACTOR } \\
6 \\
\text { Job } \\
\text { perfor- } \\
\text { mance }\end{array}$ \\
\hline PERF1 & $-0,007$ & 0,080 & 0,071 & $-0,024$ & 0,276 & $\underline{0,445}$ \\
\hline PERF2 & 0,006 & $-0,033$ & 0,037 & 0,025 & 0,003 & $\underline{0,712}$ \\
\hline PERF3 & $-0,089$ & 0,118 & 0,009 & 0,000 & 0,070 & $\underline{0,828}$ \\
\hline PERF4 & 0,209 & $-0,013$ & $-0,052$ & $-0,006$ & $-0,026$ & $\underline{0,512}$ \\
\hline OC2 & $\underline{0,846}$ & 0,112 & $-0,053$ & 0,032 & $-0,087$ & $\overline{0,028}$ \\
\hline OC4 & $\underline{0,572}$ & 0,107 & 0,114 & $-0,033$ & 0,018 & $-0,034$ \\
\hline OC5 & $\underline{0,836}$ & 0,018 & $-0,027$ & 0,095 & 0,136 & $-0,029$ \\
\hline OC6 & $\overline{0,609}$ & 0,052 & 0,096 & $-0,004$ & 0,053 & 0,187 \\
\hline OC7 & $\overline{0,769}$ & $-0,048$ & 0,082 & 0,106 & 0,141 & 0,019 \\
\hline OC9 & $\underline{0,724}$ & 0,022 & 0,057 & 0,105 & $-0,006$ & 0,101 \\
\hline ALPY1 & 0,150 & 0,077 & $-0,062$ & $\underline{0,739}$ & $-0,101$ & 0,069 \\
\hline ALPY2 & $-0,007$ & 0,265 & 0,056 & $\underline{0,577}$ & 0,159 & $-0,104$ \\
\hline ALPY3 & $-0,075$ & 0,231 & 0,011 & $\overline{0,542}$ & 0,264 & $-0,109$ \\
\hline ALPY4 & 0,128 & $-0,034$ & 0,039 & $\underline{0,826}$ & $-0,080$ & 0,065 \\
\hline ALFB1 & 0,076 & $\underline{0,847}$ & 0,007 & 0,065 & $-0,040$ & 0,029 \\
\hline ALFB2 & 0,035 & $\underline{0,911}$ & $-0,059$ & $-0,067$ & 0,055 & 0,023 \\
\hline ALFB3 & 0,025 & $\overline{0,779}$ & 0,075 & 0,113 & $-0,012$ & 0,022 \\
\hline ALFB4 & 0,086 & $\underline{0,657}$ & 0,048 & 0,265 & $-0,136$ & 0,107 \\
\hline ALRP1 & $-0,067$ & $-0,101$ & $\underline{0,721}$ & 0,167 & 0,011 & 0,038 \\
\hline ALRP2 & 0,083 & $-0,007$ & $\underline{0,807}$ & 0,010 & 0,015 & $-0,081$ \\
\hline ALRP3 & 0,152 & 0,103 & $\underline{0,754}$ & $-0,135$ & 0,052 & $-0,085$ \\
\hline ALRP4 & $-0,020$ & 0,046 & $\underline{0,747}$ & $-0,082$ & $-0,036$ & 0,125 \\
\hline ALGR1 & 0,084 & 0,141 & 0,009 & $-0,023$ & $\underline{0,701}$ & 0,027 \\
\hline ALGR2 & 0,354 & $-0,049$ & 0,009 & 0,020 & $\underline{0,584}$ & 0,056 \\
\hline ALGR3 & 0,086 & $-0,074$ & $-0,027$ & 0,031 & $\overline{0,712}$ & 0,033 \\
\hline $\begin{array}{l}\text { ALGR4 } \\
\text { Eigen }\end{array}$ & $-0,106$ & $-0,024$ & 0,090 & $-0,006$ & $\underline{0,643}$ & 0,078 \\
\hline Values & 3,525 & 2,820 & 2,372 & 2,037 & 2,023 & 1,788 \\
\hline
\end{tabular}

Note: Loadings greater than 0,400 were considered significant
TABLE 3

THE EMPIRICAL FACTOR SRUCTURE

\begin{tabular}{|c|c|c|}
\hline Variables & Items & \\
\hline Job performance & PERF & $1,2,3,4$ \\
\hline Organisational commitment & OC & $2,4,5,6,7,9$ \\
\hline Satisfaction with fringe benefits & ALFB & $1,2,3,4$ \\
\hline Satisfaction with peer relations & ALRP & $1,2,3,4$ \\
\hline Satisfaction with monetary remuneration (pay) & ALPY & $1,2,3,4$ \\
\hline Satisfaction with growth needs & ALGR & $1,2,3,4$ \\
\hline
\end{tabular}

The factor analysis results, shown in Table 2 and summarised in Table 3, show that all the items loaded as expected, except for three organisational commitment items (OC1, OC3 and OC8), which were below the item-to-total correlation of 0,400 . The items listed in Table 3 were therefore used in all subsequent statistical procedures.

\section{Motivation, organisational commitment and job performance levels}

Mean scores for all constructs were calculated to assess the levels of employee motivation, organisational commitment and performance intentions (as a surrogate measure of job performance). Table 4 depicts the mean scores of the constructs. As explained in the methodology above, mean scores of below $60 \%$ indicate low levels for the variables investigated in this study.

TABLE 4

MEAN SCORES OF VARIABLES

\begin{tabular}{lcc}
\hline Variable & $\begin{array}{c}\text { Mean score } \\
\text { (on 7-point scale) }\end{array}$ & $\begin{array}{c}\text { Percentage } \\
\text { mean score } \\
\div 7 \times 100)\end{array}$ \\
\hline Performance intentions & 4,95 & 70,7 \\
Organisational commitment & 3,94 & 56,3 \\
Satisfaction with fringe benefits & 3,23 & 46,1 \\
Satisfaction with peer relations & 4,72 & 67,4 \\
Satisfaction with monetary remuneration & 3,13 & 44,7 \\
Satisfaction with growth factors & 5,22 & 74,6 \\
\hline
\end{tabular}

Note: mean scores of below 4,2 (60\%) are regarded as "low"

Table 4 shows low levels of satisfaction with fringe benefits and monetary remuneration, but high levels of satisfaction with peer relations and growth needs. To the extent that fringe benefits and monetary remuneration motivate the sampled respondents, their work motivation is low. Their work motivation is however high as far as satisfaction with peer-relations and growth needs is concerned. The proposition (P1) that employees in tertiaryeducation institutions will exhibit low levels of motivation due to organisational restructuring, is therefore accepted as far as satisfaction with peer relations and growth needs is concerned, but not accepted as far as satisfaction with monetary remuneration and fringe benefits is concerned.

Table 4 also shows low levels of organisational commitment. The proposition P2, that employees in tertiary-education institutions undergoing organisational restructuring will exhibit low levels of organisational commitment, is therefore accepted.

The empirical results indicate high levels of performance intent (proposition P3 is not accepted). This means that, although the 
respondents in this study exhibit low organisational commitment and low satisfaction with monetary remuneration and fringe benefits, they still show a high level of performance intent.

The interrelationships between employee motivation, organisational commitment and job performance

To empirically evaluate the various relationships depicted in Figure 1, a series of three multiple regression analyses were conducted using the computer program SAS (SAS, 1988). The results of the multiple regression analyses are summarised in Table 5 and graphically depicted in Figure 2 .

\section{TABle 5}

EMPIRICAL RESULTS: MULTIPLE REGRESSION ANALYSIS

\begin{tabular}{lcl}
\hline $\begin{array}{l}\text { Dependent variable: Organisational commitment } \\
\text { Independent variable }\end{array}$ & Estimate & $\begin{array}{l}\text { Exceedance } \\
\text { probability }\end{array}$ \\
\hline Intercept & 1,262427575 & 0,6166 \\
Monetary remuneration & 0,247019690 & $0,0489^{* *}$ \\
Fringe benefits & 0,559579805 & $0,0001^{* * *}$ \\
Peer relations & 0,279165012 & $0,0010^{* * *}$ \\
Growth needs & 0,366286909 & $0,0002^{* * *}$ \\
$\mathrm{R}^{2}=47,0 \%$ & & \\
\hline
\end{tabular}

Dependent variable: Job performance

\begin{tabular}{lll} 
Independent variable & Estimate & $\begin{array}{l}\text { Exceedance } \\
\text { probability }\end{array}$ \\
\hline Intercept & 14,61672462 & 0,0001 \\
Monetary remuneration & $-0,07586131$ & 0,2005 \\
Fringe benefits & 0,15997609 & $0,0071^{* * *}$ \\
Peer relations & 0,04554739 & 0,2502 \\
Growth needs & 0,21724527 & $0,0001^{* * *}$ \\
$\mathrm{R}^{2}=23,9 \%$ & &
\end{tabular}

Dependent variable: Job performance

\begin{tabular}{lrl} 
Independent variable & Estimate & $\begin{array}{l}\text { Exceedance } \\
\text { probability }\end{array}$ \\
\hline Intercept & 17,37904772 & 0,0001 \\
Organisational commitment & 0,18385439 & $0,0001^{* * *}$ \\
$\mathrm{R}^{2}=21,6 \%$ & &
\end{tabular}

$\mathrm{R}^{2}=21,6 \%$

Note: $\quad * * p<0,05$

$* * * \mathrm{p}<0,01$

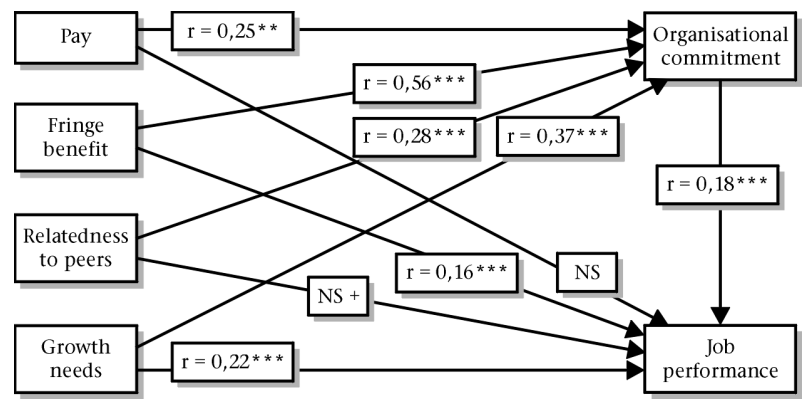

Note: NS $=$ non significant

$* *=p<0,05$

$* * *=\mathrm{p}<0,01$

Figure 2: The empirical results: multiple regression analyses

Figure 2 shows that organisational commitment is a significant determinant of employee job performance $(r=0,18, p<0,01)$. In other word, the hypothesis (H1) is accepted. This means that the low levels of organisational commitment reported in Table 4 above have the potential to decrease the job performance of the employees in a restructuring institution.

The empirical results also show that satisfaction with all the motivational elements of the Alderfer ERG theory are significantly and positively related to organisational commitment (hypotheses H2, H4, H6 and H8 accepted). This indicates that low levels of satisfaction with the Alderfer motivational needs will lead to low organisational commitment.

The results show that only satisfaction with fringe benefits and growth needs is significantly related to job performance (hypotheses $\mathrm{H} 5$ and $\mathrm{H} 9$ accepted). This means that, in the context of organisational restructuring, satisfaction with fringe benefits and growth factors will have a direct influence on the job performance of employees.

The results, however, indicate that satisfaction with monetary remuneration and peer relations is not significantly related to employee job performance (hypotheses H3 and H7 not accepted). In other words, satisfaction with monetary remuneration and peer relations is not a major concern for employees in a restructuring tertiary-education institution.

The empirical results on Table 5 show that the Alderfer needs explain $47,0 \%$ of the variance in organisational commitment. In other words, monetary remuneration, fringe benefits, peer relations and growth needs are important determinants of employees' organisational commitment.

Table 5 also shows that organisational commitment explains $21.6 \%$ of the variance in employee job performance. Among other factors, organisational commitment has a significant influence on employees' job performance.

The results show that the Alderfer needs explained 23.9\% of the variance in job performance. This means that fringe benefits and growth factors (challenging assignments, utilisation of a wide range of abilities, learning new things and involvement in decision-making, and advancement opportunities) are important determinants of employees' job performance.

\section{DISCUSSION}

The restructuring of higher education is a worldwide phenomenon, which is caused by major economic factors. It is against this background that Finkelstein (2003) asks whether resistance against this restructuring should at all be made. If no such resistance is possible, the consequences of highereducation restructuring in South Africa should at least be investigated so that the process could be managed more effectively.

Finkelstein (2003) compared the restructuring of the American higher-education system to that country's restructuring of its health care system. Finkelstein (2003) is of the opinion that the havoc that was brought about by the restructuring of the American health care system in the two decades preceding 2003 , seriously threatened the quality of health care in that country. Market mechanisms got out of hand as far as important social values regarding health care availability, quality control and costs (affordability) were concerned and important interventions became necessary. These interventions included corrective legislation, government regulation and professional medical associations protecting the rights of medical practitioners. Government interventions in the restructuring of higher education in the United States of America, however, reinforced the unfettered operation of market forces, while professional accreditation associations experienced political pressure to dismantle traditional academic standards. This state of affairs prompted stakeholders in higher education to investigate specific courses of action to "assume their individual stewardship responsibilities for the future of the university and of liberal learning" (Finkelstein, 2003). The question is whether the process of the restructuring of higher education in South Africa has reached or will be 
reaching this point at some time. To answer this question, an interpretation of the empirical results of the present study, linked to the experiences of other countries in this regard, will shed more light on the situation.

The experiences of other countries provide a basis to determine what could be expected in the South African restructuring process. Stakeholders can therefore proactively plan for the expected consequences of this process.

The consequences of the higher education restructuring process in other countries were both positive and negative. The positive consequences of the higher-education restructuring in Australia reported by Wood and Meek (2002) include: a more responsive and industry-relevant tertiary-education system; improved skill and capacity by managers of higher education institutions to develop new student markets, especially the million-dollar overseas student; and the reduction of financial dependence on government.

Various negative consequences of higher-education restructuring in other countries have also been reported. These include: the highly selective nature of student recruitment which leads to more exclusions of students from tertiary education and the concomitant further stratification of life chances across socio-economic groups (Gumport, 2000; Manicas, 1998); the managing of the restructuring process for personal gain rather than the interest of the new institution (Mildred, 2002); increases in costs due to travelling between sites and upgrading of services at different sites (Curri, 2002); the inability to exercise the promised wider choice of educational programmes due to the realities of multi-campus delivery and time-table contraints (Mildred, 2002); the rise of academic consumerism, which changes public higher education from knowledge-seeking institutions to business enterprises providing narrow offerings for different segments of the student population (Gumport, 2000); tensions (turf-fighting) in areas of academic specialisation and overall organisational turmoil that nullifies the intended positive objectives of restructuring (Mildred, 2002); increased workloads of both academic and administrative staff (Mildred, 2002); and the polarisation between the top management and the member institutions (Curri, 2002).

More or less similar positive and negative consequences of the higher-education restructuring process in South Africa have been reported. While it might be too early to expect that the above-mentioned spin-offs of higher-education restructuring in South Africa have already manifested themselves, at least one outcome has been confirmed. The foreign student market in South Africa, for example, has grown considerably. Futuse (2004) reports that the number of foreign students enrolling at South Africa universities has increased from 34770 in 1999 to 47000 in 2003, generating R1,4-billion of the R21,5-billion earned by highereducation institutions in 2003.

Popular literature and research studies, on the other hand, have also highlighted the following negative effects of the restructuring of higher education: destabilisation caused by student and staff protests (Naidu, 2005); unscrupulous jockeying for senior positions (Mkhize, 2005); exclusion of students from higher-education institutions due to higher study fees (Kotecha, 2005; Naidu, 2005); demoralisation, demotivation, uncertainty and feelings of disempowerment (Fourie, 1999).

The preceding findings of restructuring of higher education provide the background against which the empirical findings of the current study are assessed.

The empirical results show that the staff of this tertiaryeducation institution exhibit low levels of organisational commitment and low satisfaction with monetary remuneration and fringe benefits. In other words, to the extent to which monetary remuneration and fringe benefits motivate the job performance of university personnel, motivation levels are low in this institution. In Alderfer's ERG model (1969), monetary remuneration and fringe benefits are needs that motivate the job performance of employees.

The low organisational commitment levels harbour negative implications for the job performance and intent to resign of the staff. Research has indicated that organisational commitment is a strong determinant of employee job performance (Boshoff \& Arnolds, 1995a; Zaccaro \& Dobbins, 1989) and intent to resign (Boshoff, Van Wyk, Hoole \& Owen, 2002; Shore, Newton \& Thornton, 1990). In the present study, as well as the Fourie (1999) study, high levels of demotivation and demoralisation among higher-education staff members involved in restructuring were recorded. It is important that managers of merged higher-education institutions monitor the commitment and motivation levels of their staff members so that timely interventions can be initiated where necessary. There are already reports that the remuneration packages of employees at merging institutions are being adjusted downwards, due to the reduction in government funding among other factors. Reduced remuneration packages, possible retrenchments and increasing workloads do not augur well for the motivation, organisational commitment and job performance levels of employees.

Low organisational commitment and demotivation do not necessarily lead to resignation due to academics' professional commitment to their work. The empirical results show that respondents of the present study exhibit a high intent to perform, despite their low satisfaction with their remuneration and fringe benefits. In other words, highereducation academics and administrators have a professional commitment towards their work. In this lies the danger that academics and administrators might still do a professional job (the expected minimum), but do not concern themselves about the growth of the organisation. While this type of calculative involvement might suit the managerial approach in the new institutions, attention should be given to what the long-term effects of such an approach would be according to Gumport (2000).

The results reveal high levels of satisfaction with peer relations and growth needs. This means that the extent to which peer relations and growth need satisfaction motivate their job performance, the motivational level of this university's staff members is high. It is also a further indication that the staff of this tertiary-education institution exhibit a professional commitment to their job, which is characterised by their identification with people doing the same job (their peers) and the utilising the training and development opportunities to improve their professional competencies. This finding is in line with Erwee (1980) who found that the academic staff of tertiaryeducation institutions exhibit a stronger professional commitment than organisational commitment.

The empirical results suggest that the effective management of peer (collegial) relations could reduce negative attitudes towards the merger process. Initiatives by management to facilitate social interaction and work-related collaborations among the staff members of the merging institutions could therefore bear fruit in terms of building a new team spirit and even enhance organisational commitment. This assertion is underscored by the empirical result that satisfaction with peer relations $(r=0,28, p<0,05)$ is positively and significantly related to organisational commitment.

The empirical results reveal that employee satisfaction with all the Alderfer needs was significantly and positively related to organisational commitment. This implies that employee 
motivation, defined in this study as the degree of satisfaction with monetary remuneration, fringe benefits, peer relations and growth needs, is an important determinant of organisational commitment and eventually also employee job performance. It also means that to the extent to which highereducation restructuring impacts employees' remuneration packages, peer relations and growth needs, these motivational elements will have a significant influence on the employees' identification with, willingness to exert extra effort on behalf of, and intent to stay with the new merged institution. The implication of this for management is that bigger demands will be made on the financial resources of the merging institutions to at the very least maintain the employees's levels of satisfaction with their monetary remuneration, fringe benefits, peer relations and growth (training, development, advancement). It must be noted that fringe benefits registered the highest correlation $(\mathrm{r}=0,56)$ with organisational commitment. This suggests that the manner in which fringe benefits will be managed during the restructuring process will be very important for the employees' organisational commitment and performance intentions.

The empirical results showed that monetary remuneration (pay) and relatedness to peers are not direct determinants of job performance, but rather indirect influencers of job performance via organisational commitment. This is an indication to management that professional employees do not view their monetary remuneration as payment for their performance, but rather as an indication of how their institutions value them. Employee perceptions of how management project their institutions' appreciation for their employees are vital during and after restructuring.

The empirical results showed a significant and positive relationship between employee satisfaction with fringe benefits and growth needs, on the one hand, and employee job performance, on the other hand. This result underscores the importance professional employees attach to fringe benefits and growth factors (training, development, advancement), as these rewards indicate the valence institutions attach to their employees. The management of fringe benefits and growth factors should therefore be important variables in the decision-making of the management of merging institutions.

To summarise: the present study has shown that employee motivation, expressed as employees' satisfaction with their monetary remuneration, fringe benefits, peer relations and growth needs, exerts a positive and significant influence on their organisational commitment, which in turn is a significantly positive determinant of job performance. If the higher-education restructuring causes lower employee motivation (as measured above), the new merged institutions will be faced with lower organisational commitment and potentially lower employee job performance. Employee dissatisfaction with monetary remuneration and growth factors will however directly lead to lower employee job performance. It is therefore important that management manage the relationship between the Alderfer needs and organisational commitment effectively during and after the restructuring process.

Finally, Rylander (2003) suggested that the measurement of organisational commitment at a single point in time during employment is a limitation in most organisational commitment research and that more longitudinal studies need to be conducted. The restructuring of higher education institutions in South Africa provides a unique opportunity to contribute to the body of knowledge on organisational commitment in that regard. To address this research gap, this study represents the first phase in a longitudinal investigation into the development of organisational commitment in a restructuring organisation.

\section{REFERENCES}

Alderfer, C.P. (1969). An empirical test of a new theory of human needs. Organisational Behaviour and Human Performance, 4, pp. 142-175.

Alpander, G.G. (19900. Relationship between commitment to hospital goals and job satisfaction: A case study of a nursing department. Health Care Management Review, 15 (4), pp. 51-62.

Aram, J.D. \& Piraino, T.G. (1978). The hierarchy of needs theory: An evaluation in Chile. Interamerican Journal of Psychology, 12 (2), pp. 179-188.

Arnolds, C.A. \& Boshoff, C. (2000). Does higher remuneration equal higher job performance?: An empirical assessment of the need-progression proposition in selected need theories. South African Journal of Business Management, 31 (2), pp. 53-64.

Bagraim, J.J. (2003). The nature and measurement of multiple commitment foci among South African workers. Management Dynamics, 12 (2), pp. 13-23.

Bennett, J. (2002a). South African workers can't get no satisfaction. Sunday Times, Business Times, 13 October, p.1.

Bennett, J. (2002b). Maturing with age. Sunday Times, Business Times, 27 October, p1.

Blackmore, J. (2002). Globalisation and restructuring of higher education for knowledge economies: New dangers or old habits troubling gender equity work in universities. Higher Education Quarterly, October, 56 (4), pp. 419-441.

Boshoff, C. \& Arnolds, C. (1995a). Employee commitment and organizational effectiveness. Management Dynamics, 4 (3), pp. 69-100.

Boshoff, C. \& Arnolds, C. (1995b). Some antecedents of employee commitment and their influence on job performance: A multi foci study. South African Journal of Business Management, 26 (4), pp. 125-135.

Boshoff, A.B., Van Wyk, R., Hoole, C. \& Owen, J.H. (2002). The prediction of intention to quit by means of biographic variables, work commitment, role strain and psychological climate. Management Dynamics, 11 (4), pp. 14-28.

Brooke, P.P., Russell, D.W. \& Price, J.L. (1988). Discriminant validity of measures of job satisfaction, job involvement and organizational commitment. Journal of Applied Psychology, 73 (2), pp. 139-145.

Carkhuff, R.R. (1986). Human processing and human productivity. Amherst, MA: Human Resource Development Press.

Clark, J. \& Koonce, R. (1995). Engaging organisational survivors. Training and development, 49 (8), pp. 22-30.

Cohen, A. (1992). Antecedents of organisational commitment across occupational groups: A meta-analysis. Journal of Organisational Behaviour, 13, pp. 539-558.

Colarelli, S.M. \& Bishop, R.C. (1990). Career commitment: Functions, correlates, and management. Group and Organizational Studies, 15 (2), pp. 158-176.

Cronbach, L.J. (1951). Coefficient alpha and the internal structure of tests. Psychometrika, 16, pp. 297-334.

Curri, G. (2002). Reality versus perception: Restructuring tertiary education and institutional organisational change A case study, Higher Education, 44 (1), pp. 133-151.

Darden, W.R., Hampton, R. \& Howell, R.D. (1989). Career versus organizational commitment: Antecedents and consequences of retail salespeople's commitment. Journal of Retailing, 65 (1), pp. 80-106.

Erwee, R. (1980). Professional and organisational commitment of university research professors. South African Journal of Business Management, 11, pp. 121-126.

Falkenberg, R. (2001). Knowledge professionals demand more savvy treatment. Sunday Times, Business Times, 4 March, p2.

Finkelstein, M. (2003). The morphing of the American academic profession: Every societal transformation in the role of higher education has brought in its wake a concomitant transformation in the faculty role, Liberation Education, Fall, 89 (4), pp. 6-14. 
Fourie, M. (1999). Institutional transformation at South African universities: Implications for academic staff, Higher Education, 38 (3), pp. 275-290.

Fox, J.B., Scott, K.D. \& Donohue, J.M. (1993). An investigation into pay valence and performance in a pay-for-performance field setting. Journal of Organisational Behaviour, 14 (7), pp. 687-693.

Frane, J., Jennrich, R.I. \& Sampson, P.F. (1990). P4M-Factor Analysis. In W.J. Dixon \& M.B. Brown (eds.) BMDP Statistical Software Manual, 1, pp. 311 337. Berkeley: University of California.

Futuse, B. (2004). SA varsities cash in on foreign students. Sunday Times, 29 August.

Gourley, B. (1995). Transformation in tertiary education. Progressio, 17 (1), pp. 20-27.

Gregersen, H.B. (1993). Multiple commitments at work and extrarole behaviour during three stages of organizational tenure. Journal of Business Research, 26, pp. 31-47.

Gumport, P.J. (2000). Academic restructuring: Organizational change and institutional imperatives, Higher Education, 39 (1), pp. 67-91.

Hampton, D.R., Summer, C.E. \& Webber, R.A. (1982). Organisational Behaviour and Practice of Management. Glenview, Illinois: Scott, Foresman and Company.

Hellriegel, D., Slocum, J.W. \& Woodman, R.W. (2001). Organizational Behaviour. Ninth Edition. Cincinnati, Ohio: South-Western College Publishing.

Hong, J.C., Yang, S.D., Wang, L.G., Chiou, E.F., Sun, F.Y. \& Huang, T.L. (1995). Impact of employee benefits on work motivation and productivity. International Journal of Career Management, 7 (6), pp. 10-14.

Jennrich, R.I. \& Sampson, P.F. (1966). Rotation for simple loadings. Psychometrika, 31, pp. 313-323.

Kotecha, P. (2005). Working out the optimal size of higher education. IZWI - Voice of HE Leadership. http://www.sauvca.org.za.

Kraak, A. (2004). Discursive tensions in South African Higher Education, 1990 to (2002). Journal of Studies in International Education, 8 (3), pp. 244-282.

Levine, H.Z. (1994). Why incentive plans cannot work. Compensation and Benefits Review, 26 (1), pp. 77-78.

Luthans, F. (1998). Organizational behavior. Singapore: McGrawHill.

Manicas, P. (1998). The radical restructuring of higher education.

(Special Issue: The University - Alternative Futures). Futures, September, 30 (7), pp. 661-667.

Marginson, S. \& Ramsden, P. (2000). Revision of papers delivered at the "Reworking the University" conference, held at Griffith University in Queensland, Australia, Journal of Higher Education Policy and Management, 22 (1), pp. 5-7.

Maslow, A.H. (1943). A theory of human motivation. Psychological Review, 50, pp. 370-396.

Matthieu, J.E. \& Farr, J.L. (1991). Further evidence for the discriminant validity of measures of organizational commitment, job involvement and job satisfaction. Journal of Applied Psychology, 76 (1), pp. 127-133.

McGregor, D. (1987). The human side of enterprise. Penguin Books.

Mildred, G. (2002). Launching the United National System: What happened in South Australia, Higher Education, 44 (1), pp. 29-51.

Mkize, T. (2005). Extreme makeover of higher education. Sunday Times, 13 March.

Mok, K.H. (2003). Globalisation and higher education restructuring in Hong Kong, Taiwan and Mainland China. Higher Education Research \& Development, 22 (2), pp. 117-129.
Mottaz, C.J. (1989). An analysis of the relationship between attitudinal commitment and behavioral commitment. The Sociological Quarterly, 30 (1), pp. 143-158.

Mowday, R.T., Porter, L.W. \& Steers, R.M. (1982). Employeeorganizational Linkages: The Psychology of Commitment, Absenteeism and Turnover. New York: Academic Press.

Mowday, R.T., Steers, R.M. \& Porter, L.W. (1979). The measurement of organizational commitment. Journal of Vocational Behaviour, 14, pp. 224-247.

Naidu, B. (2005). Merger mayhem convulses SA's universities. Sunday Times, 6 March.

Nunnally, J. (1978). Psychometric Theory. Second Edition. New York: McGraw-Hill. Oliver, N. (1990). Work rewards, work values, and organisational commitment in an employeeeowned firm : Evidence from the UK. Human Relations, 43 (6), pp. 513-526.

Prokopenko, J. (1987). Productivity Management: A practical handbook. International Labour Office, Geneva.

Robbins, S.P. (1998). Organizational behavior: Concepts, controversies, applications. Upper Saddle River, NJ: Prentice-Hall.

Rylander, D. (2003). Changes in organizational commitment for sales force newcomers: An exploratory look at early employment influences. Retrieved November 4, 2003, from the World Wide Web: http://a-cme.org/PDFfiles/(2003)-Paper24.pdf

SAS Institute Inc. (1988). SAS/STATTM. User's Guide, Release 6.03 Edition. Cary, N.C.: SAS Institute Inc.

Shore, L.M. Newton, L.A. \& Thornton III, G.C. (1990). Job and organisational attitudes in relation to employee behavioura intentions. Journal of Organisational Behaviour, II, pp. 5767.

Smith, C.S. and Tisak, J. (1993). Discrepancy measures of role stress revisited: New perspectives on old issues. Organisational Behaviour and Human Decision Processes, 56, pp. 258-307.

Stahl, M.J. (1986). Managerial and technical motivation: Assessing needs for achievement, power and affiliation. New York: Praeger Publishers.

Stein, M. \& Hollowitz, J. (1992). Psyche at work: Workplace applications of the Jungian Analytical Psychology. Wilmette, IL: Chiron Publications.

Sumerlin, J.R. \& Norman, R.L. (1992). Self-actualisation and homeless men: A known-group examination of Maslow's hierarchy of needs. Journal of Social Behaviour and Personality, 7 (3), pp. 469-481.

Van Rensburg, L. (1998). Resultate van die loodstudie oor nuweling dosente se belewenis (houding) ten opsigte van transformasie, Unpublished report.

Viljoen, J.P. \& Rothman, S. (2002). Transformation in a tertiaryeducation institution: A case study. Management Dynamics, 11 (2), pp. 2-10.

Wallace, J.E. (1995). Organizational and professional commitment in professional and nonprofessional organisations. Administrative Science Quarterly, 40 (2), pp. 228-256.

Willemse, A. (2002). When the HR people master their talent, work becomes a symphony. Sunday Times, Business Times, 31 March, p2.

Wood, F. \& Meek, L. (2002). Over-received and underfunded? The evolving policy context of Australian higher education research and development. Journal of Higher Education Policy and Management, 24 (1), pp. 7-25.

Woordard, C. (1997). Experts see Russian higher education becoming diverse and decentralized. The Chronicle of Higher Education, November, 44 (13), pp. A43-45.

Workplace changes employees want to see. (1999). Management Review, January, p6.

Zaccaro, S.J. \& Dobbins, G.H. (1989). Contrasting group and organizational commitment: Evidence for differences among multilevel attachments. Journal of Organizational Behaviour, 10 , pp. $267-273$. 